\title{
Teknologi Pengolahan Yoghurt Sebagai Diversifikasi Produk Susu Kambing pada Kelompok Ternak Desa Wonoasri Kecamatan Tempurejo Kabupaten Jember
}

\author{
Merry Muspita Dyah Utami*, Dadik Pantaya, Hariadi Subagja, Niati Ningsih dan Aryanti \\ Candra Dewi \\ Politeknik Negeri Jember \\ *Corresponding Author: merry.mdu @ polije.ac.id
}

\begin{abstract}
ABSTRAK
Tujuan kegiatan pengabdian adalah memberdayakan kelompok peternak kambing Peranakan Etawa (PE) desa Wonoasri Kecamatan Tempurejo Kabupaten Jember dengan edukasi pengolahan susu kambing menjadi yoghurt. Prospek pemasaran yoghurt susu kambing mempunyai peluang pasar di masyarakat, meningkatkan harga jual susu kambing, dan menjadi solusi pemanfaat susu kambing yang tidak terjual. Metode yang digunakan adalah pelatihan pembuatan yoghurt dan pelatihan manajemen usaha yoghurt. Kegiatan pengabdian dilakukan pada bulan Juni sampai November 2019. Hasil yang diperoleh kelompok peternak dapat membuat produk olahan yoghurt dan menerapkan manajemen usaha yoghurt. Kesimpulan dari kegiatan ini adalah seluruh anggota kelompok ternak dapat membuat yoghurt sesuai prosedur dan dapat menerapkan manajemen usaha yoghurt sebagai bisnis yang berkelanjutan. Hasil pembuatan yoghurt yang disukai adalah yoghurt yang dibuat dengan konsentrasi $1 \%$ dengan varian rasa strawberry. Kegiatan pembuatan yoghurt dapat meningkatkan pendapatan dan kesejahteraan peternak.
\end{abstract}

Kata kunci: peternak, susu kambing, desa Wonoasri, yoghurt

\begin{abstract}
Community service activities aim to empower the Peranakan Ettawa (PE) goat group of Wonoasri village, Tempurejo Sub-District, Jember Regency with education on processing goat milk into yoghurt. The prospect of marketing goat milk yoghurt has a market opportunity in the community, increasing the selling price of goat milk, and being a solution to the utilization of unsold goat milk. Community service activities are carried out from June to November 2019. The results obtained by the farmer group can make yoghurt processed products and implement yoghurt business management. This activity concludes that all members of the livestock group can make yoghurt according to procedures and can implement yoghurt business management as a sustainable business. The preferred yoghurt is yoghurt made with a concentration of $1 \%$ with a strawberry flavor variant. Yoghurt making activities can increase farmers' income.
\end{abstract}

Keywords: farmer, goat milk, Wonoasri village, yoghurt

\section{PENDAHULUAN}

Salah satu ternak bangsa kambing perah yang dikembangkan di Indonesia yaitu kambing Peranakan Etawa (PE). Kambing PE merupakan hasil perkawinan silang antara kambing Etawa dengan kambing lokal. Kambing Etawa termasuk tipe dwiguna yakni sebagai penghasil susu dan daging (Heriyanta et al., 2014). Produksi susu kambing PE berkisar antara 0,452,2 liter/hari (Sodiq dan Abidin, 2008).
Susu Kambing PE memiliki nilai nutrisi hampir sama dengan susu sapi, salah satu keunggulannya adalah tingginya proporsi butirbutir lemak ukuran kecil rantai pendek dan sedang (Sutama, 2008). Butiran lemak susu kambing berukuran 1-10 milimikron sama dengan susu sapi, tetapi jumlah butiran lemak yang berdiameter kecil dan homogen lebih banyak terdapat pada susu kambing, sehingga susu kambing lebih mudah dicerna oleh organ pencernaan manusia, serta tidak menimbulkan 
diare bagi yang mengkonsumsinya. Khasiat susu kambing lainnya, membantu memulihkan orang yang baru sembuh dari sakit, mampu mengontrol kadar kolesterol dalam darah, serta untuk kesehatan kulit (Sodiq dan Abidin, 2008).

Kelompok peternak kambing Desa Wonoasri memelihara kambing PE dengan produksi per ekor 1-1,5 liter/hari. Dari 15 orang peternak kambing PE masing-masing mempunyai kambing rata-rata 4 sampai 5 ekor, sehingga produksi susu kambing per hari 90 sampai 120 liter. Produksi susu tersebut hanya terserap oleh pasar berkisar 30-40 liter susu per hari sehingga susu kambing banyak terbuang. Hal ini karena susu kambing memiliki gizi tinggi yang sangat cocok untuk pertumbuhan dan perkembangan mikroba sehingga hanya mempunyai waktu yang sangat singkat untuk layak konsumsi.

Rendahnya serapan pasar susu kambing disebabkan oleh belum membudayanya mengkonsumsi susu kambing dan konsumen kurang menyukai bau susu kambing yang cukup tajam dan khas seperti halnya bau daging kambing. Permasalahan tersebut sangat merugikan anggota kelompok ternak karena biaya pemeliharaan kambing menjadi beban ekonomi masyarakat sehingga menyebabkan minat memelihara kambing masyarakat desa Wonoasri menjadi menurun. Untuk itu diperlukan solusi agar produksi susu kambing anggota kelompok ternak tidak terbuang dengan diversifikasi produk melalui teknologi pengolahan yoghurt pada susu kambing. Pembuatan yogurt merupakan solusi untuk meningkatkan konsumsi susu kambing, mengurangi bau khas, dan memperpanjang masa simpan.

Yoghurt dibuat dengan fermentasi menggunakan bakteri Lactobacillus bulgaricus dan Streptococccus thermophilus yang diinokulasikan pada susu akan menghasilkan konsistensi susu yang semi-padat dan rasa yang agak asam manis (Paramitha, 2016) serta dapat menghilangkan bau tajam susu kambing. Susu yang digunakan untuk pembuatan yoghurt harus bebas dari bahan yang menghambat atau mencegah pertumbuhan organisme starter seperti antibiotik, pengawet, desinfektan, dan bakteriofag (Obi et al., 2016). Yoghurt mengandung kadar protein 4-6\%, kadar lemak $0,1-1 \%$, laktosa $2-3 \%$, dan asam laktat $0,6-1,3 \%$ (Prasetyo, 2010).

Yoghurt merupakan makanan fungsional (Suter dan Suter, 2013) yang mengandung probiotik, prebiotik, dan sinbiotik. Probiotik didefinisikan sebagai suplemen makanan berupa mikroba hidup yang menguntungkan dan mempengaruhi inang dengan meningkatkan keseimbangan mikroba ususnya (Champagne et al., 2005). Prebiotik adalah bahan makanan yang tidak dapat dicerna yang secara menguntungkan mempengaruhi inang dengan merangsang pertumbuhan dan aktivitas satu atau sejumlah bakteri dalam usus besar. Sinbiotik adalah kombinasi probiotik dan prebiotik yang menguntungkan mempengaruhi inang dengan meningkatkan kelangsungan hidup dan implantasi suplemen makanan mikroba hidup dalam saluran pencernaan dengan merangsang pertumbuhan secara selektif dan mengaktifkan metabolisme satu atau sejumlah terbatas bakteri pemacu kesehatan (Klaenhammer, 2000). Manfaat mengkonsumsi yoghurt yang mengandung probiotik antara lain meningkatkan pencernaan laktosa dan mencegah gangguan pencernaan (Widiyaningsih, 2011), meningkatkan sistem kekebalan tubuh, mencegah infeksi Helicobacter pylori, mencegah osteoporosis, mengurangi sembelit, meningkatkan penyerapan nutrisi, dan mengurangi kolesterol darah (Utaminingrum dan Utaminingrum, 2012).

Pembuatan susu kambing menjadi yoghurt akan memberikan alternatif produk susu kambing yang bergizi tinggi dan disukai masyarakat, sehingga kendala pemasaran susu kambing dapat dipecahkan. Peningkatan daya jual susu kambing dan nilai jual yoghurt akan meningkatkan pendapatan peternak sehingga memperbaiki taraf hidup peternak kambing. Kegiatan pengabdian ini juga melakukan edukasi manajemen usaha dengan pelatihan manajemen usaha yoghurt untuk anggota kelompok agar produksi yoghurt dapat dikelola dengan manajemen produksi yang efisien. Peningkatan pendapatan peternak kambing akan memotivasi masyarakat Desa Wonoasri untuk beternak kambing.

\section{METODE}

Kegiatan pengabdian ini dibagi menjadi dua, yaitu pelatihan pembuatan yoghurt dan pelatihan manajemen usaha. Pelatihan pembuatan yoghurt dilakukan dengan sosialisasi dan pengenalan, mulai dari pengenalan karakteristik susu kambing, proses fermentasi, karakteristik mikroba yang digunakan untuk fermentasi, proses pembuatan yoghurt, sampai 
dengan pengujian kualitas yoghurt. Setalah peternak memahami karakteristik sampai dengan kualitas yoghurt, selanjutnya dilakukan praktik pembuatan yoghurt.

Pembuatan yoghurt meliputi: pasteurisasi, pendinginan, penginokulasian, pemeraman dan penyimpanan. Pasteurisasi dilakukan untuk membunuh mikroba patogen dan mikroba pembusuk sehingga kualitas dan keamanan produk dapat dipertahankan, selain itu berfungsi juga untuk mendenaturasi protein susu dengan mengubah struktur proteinnya sehingga meningkatkan gelasi dan kepadatan produk yogurt yang dihasilkan. Pasteurisasi pada suhu $185^{\circ} \mathrm{F}\left(85^{\circ} \mathrm{C}\right)$ selama 30 menit atau jika menggunakan suhu $203^{\circ} \mathrm{F}\left(95^{\circ} \mathrm{C}\right)$ selama $10-20$ menit.

Setelah proses pasteurisasi, susu didinginkan hingga suhu $107-110^{\circ} \mathrm{F}\left(41-43^{\circ} \mathrm{C}\right)$ agar terjadi fermentasi bakteri asam laktat. Suhu susu yang tinggi akan menyebabkan kematian bakteri starter yang diinokulasikan. Setelah tercapai susu $41-43^{\circ} \mathrm{C}$ bakteri starter Lactobacillus bulgaricus dan Streptococcus thermophiles ditambahkan pada susu masingmasing sebanyak $1 \%$ dan $3 \%$.

Setelah inokulasi, susu dimasukkan ke dalam wadah yang steril dan diinkubasi dalam inkubator pada suhu $110^{\circ} \mathrm{F}\left(43^{\circ} \mathrm{C}\right)$ untuk proses fermentasi selama 6 sampai 12 jam. Selama fermentasi bakteri akan menggunakan laktosa untuk menghasilkan asam laktat yang akan menurunkan $\mathrm{pH}$ susu sampai dibawah 4,6. Setelah proses inkubasi, dilakukan pemeriksaan kualitas yoghurt dan ditambahkan rasa strawberry, kemudian disimpan dalam lemari es pada suhu $40^{\circ} \mathrm{F}\left(4^{\circ} \mathrm{C}\right)$ untuk menghentikan proses fermentasi. Pengolahan susu menjadi yoghurt akan meningkatkan masa simpan sampai 2 atau 3 minggu (Surajudin dan Purnomo, 2005).

Pelatihan manajemen usaha dilaksanakan setelah peternak dapat memproduksi yoghurt, yaitu dilakukan edukasi tentang manajemen usaha yang meliputi: potensi, peluang, modal, pengemasan, pemasaran agar yoghurt dapat dipasarkan sesuai standar mutu. Pelatihan manajemen usaha dilaksanakan dengan cara penyuluhan, sosialisasi dan pendampingan. Kegiatan evaluasi dan monitoring dilakukan setiap kegiatan pengabdian selesai dilaksanakan. Seluruh tim pengabdian mengevaluasi pelaksanaan kegiatan secara internal dan selanjutnya akan dilakukan evaluasi bersama mitra kelompok ternak kambing Desa Wonoasri.
Evaluasi dilakukan untuk menganalisis keberhasilan program dan mengidentifikasi rencana keberlanjutan program.

\section{HASIL DAN PEMBAHASAN}

Kegiatan pengabdian yang dilaksanakan di Desa Wonoasri Kecamatan Tempurejo Kabupaten Jember ini terdiri atas persiapan, sosialisasi dan pengenalan produk yoghurt, pelatihan pembuatan yoghurt, pelatihan manajemen usaha yoghurt, dan evaluasi semua kegiatan yang telah dilakukan.

\section{Kegiatan Persiapan}

Kegiatan persiapan dilakukan meliputi survei lokasi, wawancara dan observasi kepada kelompok ternak kambing PE Desa Wonoasri untuk mengidentifikasi beberapa permasalahan yang dihadapi kelompok peternak kambing PE dan upaya penyelesaian yang dapat diberikan. Hasil dari kegiatan persiapan ini adalah adanya kesepakatan antara tim pengabdian dan ketua kelompok peternak kambing PE, yaitu: pendataan jumlah anggota kelompok ternak kambing di Desa Wonoasri yang mengikuti kegiatan pengabdian dan penyusunan jadwal (hari) pengabdian. Ketua kelompok peternak kambing PE berperan aktif mengkoordinir seluruh anggota kelompok untuk mengikuti pelatihan sesuai jadwal yang telah ditentukan. Salah satu aktivitas kegiatan persiapan ditampilkan pada Gambar 1.

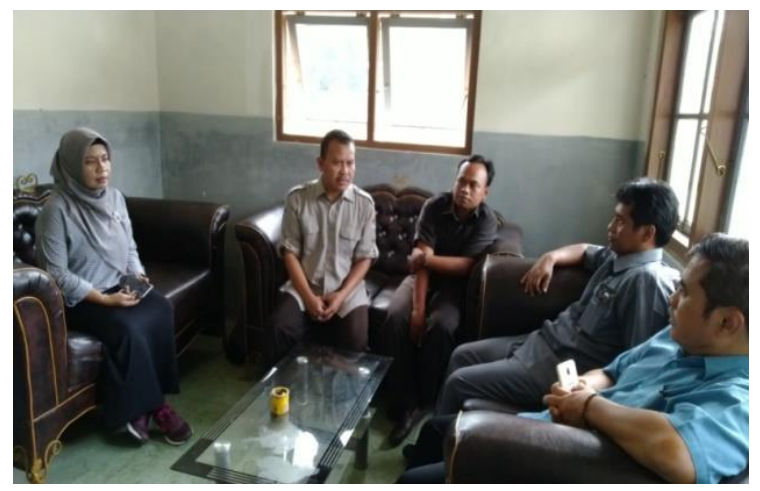

Gambar 1. Observasi dan Penyusunan Jadwal Kegiatan ke Desa Wonoasri Kecamatan Tempurejo Kabupaten Jember

\section{Sosialisasi dan Pelatihan Pembuatan Yoghurt}

Untuk mengenal yoghurt dilakukan sosialisasi dan pengenalan pengolahan susu menjadi yoghurt, berupa penyuluhan yang dihadiri oleh 10 orang peserta yang terdiri atas anggota kelompok ternak kambing perah PE dan 
Perangkat Desa Wonoasri. Kambing PE memiliki potensi genetik sebagai kambing dwiguna yaitu penghasil daging dan susu. Susu kambing mengandung nutrien yang cukup baik serta dapat meningkatkan daya tahan tubuh (Sodiq dan Abidin, 2008).

Materi yang diberikan pada kegiatan ini adalah pengenalan kandungan nutrisi, sifat-sfiat dan karakteristik susu kambing dan pengolahan susu kambing menjadi yoghurt. Kegiatan ini berlangsung di Laboratorium Produksi Ternak Politeknik Negeri Jember yang dihadiri oleh 10 peserta pelatihan. Selanjutnya dilakukan praktik pembuatan yoghurt secara langsung. Hasil praktik pembuatan yoghurt ini ditampilkan pada Gambar 2.

Yoghurt yang dibuat pada pengabdian ini menggunakan dua konsentrasi starter yang berbeda yaitu $1 \%$ dan $3 \%$ dengan varian rasa plain (tanpa penambahan perasa) dan penambahan perasa strawberry, sehingga terdapat empat macam yoghurt, yaitu: (1) starter $1 \%$, plain, (2) starter $1 \%$ strawberry, (3) starter $3 \%$, plain, dan (4) starter 3\%, strawberry. Pengujian hedonik perbedaan konsentrasi starter dan pemberian perasa dicantumkan pada Tabel 1.

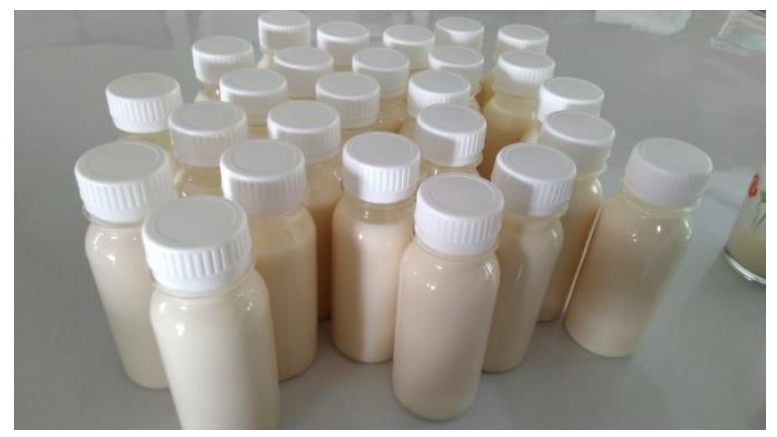

Gambar 2. Hasil Pelatihan Pembuatan Yoghurt Desa Wonoasri

Tabel 1. Hasil Uji Hedonik Yoghurt Susu Kambing Desa Wonoasri

\begin{tabular}{lcccc}
\hline \multicolumn{1}{c}{ Jenis Yoghurt } & Warna & Aroma & Keasaman & Kesukaan \\
\hline Starter 1\%, plain & $1,36 \pm 0,49^{\mathrm{a}}$ & $2,56 \pm 0,51^{\mathrm{a}}$ & $2,12 \pm 0,78^{\mathrm{a}}$ & $3,44 \pm 0,65^{\mathrm{b}}$ \\
Starter 1\% strawberry & $3,60 \pm 0,65^{\mathrm{b}}$ & $4,40 \pm 0,58^{\mathrm{b}}$ & $3,04 \pm 0,73^{\mathrm{b}}$ & $4,20 \pm 0,71^{\mathrm{c}}$ \\
Starter 3\%, plain & $1,56 \pm 0,51^{\mathrm{a}}$ & $2,72 \pm 0,61^{\mathrm{a}}$ & $3,68 \pm 0,69^{\mathrm{b}}$ & $2,48 \pm 0,51^{\mathrm{a}}$ \\
Starter 3\%, strawberry & $3,80 \pm 0,71^{\mathrm{b}}$ & $4,28 \pm 0,67^{\mathrm{b}}$ & $4,20 \pm 0,76^{\mathrm{b}}$ & $3,12 \pm 0,72^{\mathrm{b}}$ \\
\hline
\end{tabular}

Keterangan: Superskrip yang berbeda menunjukkan perbedaan yang signifikan $(\mathrm{P}, 0,05)$

Dari hasil pengujian hedonik yang dilakukan terhadap warna menunjukkan panelis lebih menyukai yoghurt dengan warna merah muda (strawberry) dibandingkan yang berwarna susu (plain), demikian pula aroma yoghurt dengan perasa strawberry lebih disukai dibandingkan yoghurt rasa plain. Rasa asam yoghurt paling kurang pada konsentrasi starter $1 \%$ plain dibandingkan yoghurt yang lain, dan berdasarkan kesukaan, panelis paling menyukai yoghurt konsentrasi starter $1 \%$ dengan rasa strawberry. Hal berkaitan dengan keasaman yoghurt dengan starter $1 \%$ yang terasa kurang asam dibandingkan dengan yoghurt starter 3\% dan rasa strawberry lebih disukai daripada plain.

Yoghurt adalah produk olahan susu kambing yang telah difermentasi dengan menggunakan bakteri asam laktat Streptococcus thermophilus dan Lactobacillus bulgaricus (Syainah et al., 2014). Susu kambing PE yang akan difermentasikan harus dipasteurisasi terlebih dahulu dengan tujuan untuk menurunkan populasi mikrobia dalam susu dan memberikan keadaan yang baik bagi pertumbuhan biakan yoghurt serta mengurangi kandungan air dalam susu.
Prinsip pembuatan yoghurt adalah adanya proses fermentasi komponen gula yang ada dalam susu, yaitu laktosa menjadi asam laktat dan asam-asam lainnya. Asam laktat yang dihasilkan selama proses fermentasi dapat meningkatkan citarasa dan meningkatkan keasaman atau menurunkan $\mathrm{pH}$-nya (Purbasari dan Abduh, 2013). Semakin rendahnya $\mathrm{pH}$ atau derajat keasaman susu setelah fermentasi akan menyebabkan semakin sedikitnya mikroba yang mampu bertahan hidup dan menghambat proses pertumbuhan mikroba patogen dan mikroba perusak susu (Usmiati et al., 2011), sehingga umur simpan susu dapat menjadi lebih lama.

\section{Pelatihan Manajemen Usaha Yoghurt}

Pelatihan manajemen usaha yoghurt merupakan upaya untuk mengelola produksi yoghurt. Adapun target kegiatan adalah kelompok peternak dapat mempunyai usaha yoghurt serta mampu mengelola usaha tersebut dengan efisien dan menguntungkan. Kelompok peternak kambing PE Desa Wonoasri diberikan wawasan tentang cara meningkatkan nilai jual susu kambing PE yang apabila dijual sebagai susu kambing segar senilai Rp 20.000,- per liter. 
dengan diolah menjadi produk yoghurt nilainya meningkat menjadi Rp 60.000,- per liter.

Pelatihan manajemen usaha diberikan materi tentang pemasaran, peluang usaha, dan manajemen usaha yang baik juga disertai dengan pembuatan packaging dan label yang menarik. Hasil peningkatan kualitas produk susu kambing PE dengan kemasan dan label ditampilkan pada Gambar 3.

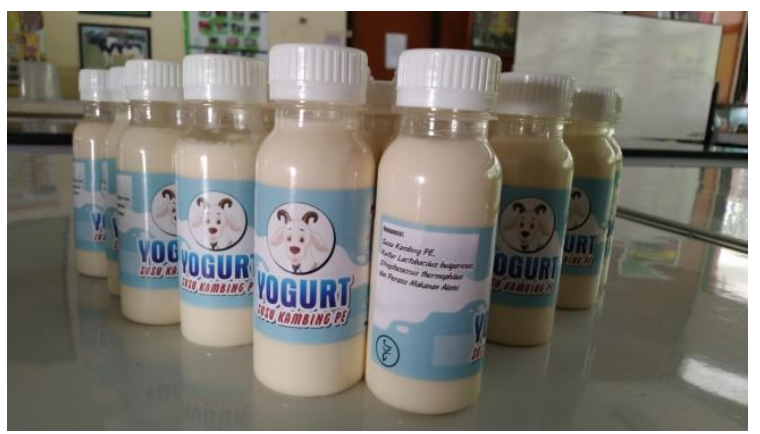

Gambar 3. Yoghurt Susu Kambing yang Sudah Dikemas dan Diberikan Label

Luaran dari kegiatan pelatihan manajemen usaha adalah adanya tambahan pengetahuan dan wawasan peternak untuk membuat suatu usaha pengolahan susu menjadi yoghurt, yaitu membuat perencanaan manajemen usaha yang baik dan benar sehingga dapat menghasilkan suatu usaha yang efisien. Hasil akhir dari kegiatan ini diharapkan peternak memiliki usaha yoghurt susu kambing dengan keuntungan yang maksimal sehingga dapat meningkatkan pendapatan dan kesejahteraan peternak.

Target pada akhir kegiatan ini adalah kelompok peternak kambing PE mampu memproduksi yoghurt dari susu kambing sesuai dengan standar mutu pembuatan yoghurt sehingga terjadi peningkatan nilai tambah susu kambing PE kelompok ternak Desa Wonoasri yang selama ini kurang dimanfaatkan. Selain itu juga dapat meningkatkan pendapatan dan kesejahteraan seluruh anggota kelompok ternak serta semua produk susu yang dihasilkan dapat terserap pasar dan tidak ada yang terbuang.

\section{KESIMPULAN}

Kegiatan pembuatan yoghurt susu kambing yang dilaksanakan di Desa Wonoasri, Kecamatan Tempurejo, Kabupaten Jember diikuti oleh 10 anggota. Beberapa hasil utama dari pelaksanaan pengabdian yang dilakukan pada mitra kelompok ternak di Desa Wonoasri yaitu (1) seluruh anggota kelompok ternak dapat melakukan pembuatan yoghurt secara mandiri dan berkelompok, mulai dari pasteurisasi, inokulasi, pemberian rasa, dan inkubasi sesuai prosedur yang benar, (2) hasil pembuatan yoghurt yang paling disukai adalah yoghurt starter $1 \%$ dengan rasa strawberry, hal ini berkaitan dengan keasaman yoghurt dengan starter $1 \%$ yang terasa kurang asam dibandingkan dengan yoghurt starter 3\%, (3) terdapat peningkatan nilai jual susu kambing yang semula dijual sebagai susu segar seharga Rp 20.000,- per liter menjadi Rp 60.000,- per liter setelah diolah menjadi yoghurt sehingga meningkatkan pendapatan dan kesejahteraan peternak, (4) seluruh anggota kelompok ternak dapat menyusun perencanaan usaha, menghitung biaya produksi dan pemasaran produk yoghurt sebagai bisnis yang berkelanjutan, dan (5) pembuatan yoghurt susu kambing merupakan solusi pemanfaatan susu kambing yang tidak terjual, sehingga peternak tidak mengalami kerugian.

\section{UCAPAN TERIMA KASIH}

Penulis mengucapkan terima kasih kepada Kemenristekdikti untuk dana penelitian PNBP pada tahun 2019 melalui Pusat Penelitian dan Pengabdian Masyarakat Politeknik Negeri Jember.

\section{DAFTAR PUSTAKA}

Champagne, C. P., Gardner, N. J., \& Roy, D. (2005). Challenges in the Addition of Probiotic Cultures to Foods. Critical Reviews in Food Science and Nutrition, 45(1), 61-84. https://doi.org/10.1080/104 08690590900144

Heriyanta, E., Ihsan, M. N., \& Isnaini, N. (2014). Pengaruh Umur Kambing Peranakan Etawah (PE) terhadap Kualitas Semen Segar. TERNAK TROPIKA Journal of Tropical Animal Production, 14(2), 1-5. Retrieved from https://ternaktropika.ub. ac.id/index.php/tropika/article/view/176

Klaenhammer, T. R. (2000). Probiotic Bacteria: Today and Tomorrow. The Journal of Nutrition, 130(2), 415S-416S. https://doi. org/10.1093/jn/130.2.415S

Obi, C. N., Olugbue, V. U., \& Mpamugo, C. P. (2016). Yoghurt Production from Powdered Milk using Mixed Lactic Acid Bacteria Starter Cultures. Saudi Journal of 
Pathology and Microbiology, 1(2), 42-49. Retrieved from http://scholarsmepub.com /wp-content/uploads/2016/08/SJPM-1242 $-49 . p d f$

Paramitha, C. V. (2016). Proses Produksi Dan Pengawasan Mutu Yoghurt Pada Cv. Cita Nasional Salatiga.

Prasetyo, H. (2010). Pengaruh penggunaan starter yoghurt pada level tertentu terhadap karakteristik yoghurt yang dihasilkan. Fakultas Pertanian, Universitas Sebelas Maret. Retrieved from https://digilib.uns.ac.id/dokumen/do wnload/14385/MjkxOTc=/Pengaruh-pen ggunaan-starter-yoghurt-pada-level-terte ntu-terhadap-karakteristik-Yoghurt-yangdihasilkan-num-3.pdf

Purbasari, A., \& Abduh, S. B. M. (2013). Nilai pH, Kekentalan, Citarasa, dan Kesukaan pada Susu Fermentasi dengan Perisa Alami Jambu Air (Syzygium Sp). Jurnal Aplikasi Teknologi Pangan, 3(4), 174177. Retrieved from http://www.jatp.ift. or.id/index.php/jatp/article/view/145

Sodiq, I. A., \& Abidin, I. Z. (2008). Meningkatkan Produksi Susu Kambing Peranakan Etawa. AgroMedia. Retrieved from https://agromedia.net/katalog/menin gkatkan-produksi-susu-kambing-peranak an-etawa/

Surajudin, F. R. K., \& Purnomo, D. (2005). Yoghurt; Susu Fermentasi yang Menyehatkan. AgroMedia. Retrieved from https://agromedia.net/katalog/yogh urt-susu-fermentasi-yg-menyehatkan/

Sutama, I. K. (2008). Pemanfaatan Sumberdaya Ternak Lokal sebagai Ternak Perah mendukung Peningkatan Produksi Susu Nasional. Wartazoa, 18(4), 207-217.
Retrieved from http://medpub.litbang.per tanian.go.id/index.php/wartazoa/article/d ownload/895/904

Suter, I. K. (2013). Pangan Fungsional dan Prospek Pengembangannya. Seminar Sehari dengan tema "Pentingnya Makanan Alamiah (Natural Food) Untuk Kesehatan Jangka Panjang”. Retrieved from https://repositori.unud.ac .id/protected/storage/upload/repositori/ID 3_19501231197602100323091304927ma kalah-gizi.pdf

Syainah, E., Novita, S., \& Yanti, R. (2014). Kajian Pembuatan Yoghurt dari Berbagai Jenis Susu dan Inkubasi yang Berbeda terhadap Mutu dan Daya Terima. Jurnal Skala Kesehatan, 5(1), 1-8. Retrieved from http://www.ejurnalskalakesehatanpoltekkesbjm.com/index.php/JSK/article/ view/10

Usmiati, S., Broto, W., \& Setiyanto, H. (2011). Karakteristik Dadih Susu Sapi yang Menggunakan Starter Bakteri Probiotik. JITV, 16(2), 141-153. Retrieved from http://medpub.litbang.pertanian.go.id/ind ex.php/jitv/article/download/643/652

Utaminingrum, F., \& Utaminingrum, F. (2012). Pengaruh Pemberian Yoghurt Kedelai Hitam (Black Soyghurt) Terhadap Kadar Kolesterol LDL Serum Pada Tikus Dislipidemia. Diponegoro University. Retrieved from https://core.ac.uk/down load/pdf/11734414.pdf

Widiyaningsih, E. N. (2011). Peran Probiotik untuk Kesehatan. Jurnal Kesehatan, 4(1), 14-20. Retrieved from https://publikasi ilmiah.ums.ac.id/bitstream/handle/11617/ 2931/2.\%20ENDANG\%20NUR\%20W.p df? sequence $=1 \&$ is Allowed $=y$ 